\title{
Evaluation of different Biomedia Performance for River Purification: Preliminary Stage
}

\author{
GASIM Hayder ${ }^{1, *}$, LARIYAH Mohd Sidek ${ }^{1}$, HAIRUN Aishah Mohiyaden ${ }^{1}$, \\ HIDAYAH Basri ${ }^{1}$, AHMAD Fauzan Mohd Sabri' ${ }^{2}$, MD. NASIR Md. Noh ${ }^{2}$
${ }^{1}$ Centre for Sustainable Technology and Environment (CSTEN), Universiti Tenaga Nasional, Malaysia

${ }^{2}$ River Basin Division, Department of Irrigation and Drainage, 50626 Kuala Lumpur, Malaysia

gasim@uniten.edu.my

Keywords: River water purification, Attached growth, Biomedia, Activated sludge.

\begin{abstract}
There is national concern about rivers pollution degree. The Malaysian Department of Irrigation and Drainage (DID) is running a project for river biological purification using biomedia to reduce the river pollution degree. This study aims to use different types of biomedia carrier for effective management of the river purification plant project. Water samples were collected and tested for various essential parameters. A biomedia laboratory setup was fabricated for the research with seven different types of biomedia, and water sampling was collected daily and weekly for analysis purposes. The experimental results show that the best removal efficiency was achieved by biomedia Type 1 and was $88 \%$ and $65.5 \%$ for biochemical oxygen demand (BOD) and chemical oxygen demand (COD), respectively. Followed by biomedia Type 3 achieved an average of 58 percentage for ammonia $\left(\mathrm{NH}_{3}-\mathrm{N}\right)$ removal. Overall, the best removal efficiency performance of biomedia Type 1 achieved the calculated rate of $68 \%$. The cleanest effluent was biomedia Type 4 . For accumulated biofilm formation, the highest total volatile solid (TVS) was the biomedia Type 4 . Finally, the best inclusive performance is biomedia Type 1. Future studies are recommended to conduct a pilot scale study with a longer time frame and to study these selective types of biomedia in anaerobic and anoxic condition.
\end{abstract}

\section{Introduction}

Rapid urbanization and industrialization has led to detrimental effects to the environment, including degradation of river water quality. Preservation and pollution prevention of river water is essential in order to maintain a stable ecosystem on earth as well as to ensure a sustainable development. Through implementation of proper analysis and environmental control, polluted river can be treated biologically. However, it is essential to understand the characteristic of each biological process to ensure that proper environment is produced and controlled effectively. Since 1978, the Department of Environment (DOE) has been monitoring the rivers in Malaysia in order to establish criterion and to measure water quality changes in river water, which includes the identification of common types of pollution sources [1]. Klang Valley rivers, the prominent source of drinking water in Malaysia, are now faced with serious problems caused by non-point sources (NPS) water pollution. Under the Eighth Malaysian Plan (2001-2005) and the Third Outline Perspectives Plan (2001-2010), Malaysian government is committed to improve river water quality and integrated river basin management. Some rivers have been set to attain Class II in Interim National River Water Quality Standards. On average, clean rivers are classified under Class II in Interim National River Water Quality Standards.

The Malaysian Department of Irrigation and Drainage (DID) is looking into methods that can be used to purify the polluted rivers, and one of the methods is biological processes with biofilm carrier. This treatment apply as attached growth bacteria of secondary biological treatment in the water purification process. Polluted rivers can be treated biologically with proper technique and environmental control. Biofilm reactors use biofilm support medium -to provide surface for active bacteria attachment- with a density close to water so that it can be kept in suspension with minimum mixing energy provided by aeration or mechanical mixing [2]. Biofilm support media is 
manufactured in various shapes and is sufficiently large so that suspended support media can be retained in the reactor by screen or wire wedges. This attached growth type application will be adapted for river purification as it increases biomass concentration and treatment ability; thereby increasing microbial concentrations and rates of contaminant degradation [3]. Since the biomass primarily grows attached to the carrier, effective surface area of the carrier is the important factor [4]. The treatment performance of the treatment is based on the filling of carrier, which allows flexibility subject to treatment load. However, the design must take into consideration river water characteristics and local circumstances [5].

River pollution occurs when pollutants are discharged directly or indirectly without proper treatment. In general, water pollutants are divided into several categories namely oxygen demanding waste, infectious agents, plant nutrients, organic chemicals, inorganic elements and compounds, sediments, radioactive materials, and heat. These pollutants cause undesirable modifications to the environment that potentially affect human life [6]. Some river purification systems adopted biological treatment plant with a string-shaped biomedia type, while others use a floating filter media type biological membrane filtering system. These systems have higher contact efficiencies and more compact units than that of an inter-conglomerate contact oxidation system [7]. Locally, there is ongoing project to apply existing as well as new technologies to purify river water. Among them are the use of gross pollutant traps, trash plants, aerated string contacted oxidation (ASCO), rubber dams, aquatic plants, pool and riffles system. Other biological techniques are under research and development [8]. The trend of water quality (2005-2012) for 473 river basins concluded that out of 473 rivers monitored in 2012, 278 (59\%) were found to be clean, 161 (34\%) slightly polluted and $34(7 \%)$ polluted [9]. Results of the analysis show that the deterioration of river water quality in the country is mainly due to discharges of sewage and domestic wastewater; animal farming; land clearing and earthworks, as well as agricultural and manufacturing activities. Domestic wastewater; surface runoff from urban areas; discharges from restaurant, wet markets and food courts; pollution from agricultural and land clearing activities; suspended solids and silts from earthwork and sand mining are the main non-point polluting sources.

For this research, various types of biomedia carriers were tested in the lab in terms of their performance. This research is expected to contribute and provide more data for the local river water treatment plant projects.

\section{Methodology}

The feeding water was prepared by collecting a raw water from a nearby lake and stored in the feeding tank then pumped continuously to as influent to the reactors. Koi fishes, rotten vegetation, leaves were installed inside the feeding tank to simulate river water condition. COD concentration of feed water was in the range of $100-200 \mathrm{mg} / \mathrm{L}$ representing a typical polluted river water [10,11]. For hydraulic retention time (HRT) setup, flowrate from feeding tank to nine reactors is set approximately 2.5 litre/hr or equivalent to $4 \mathrm{hrs} \mathrm{HRT}$ as it is recommended to be above $3 \mathrm{hrs}$ [12]. The flowrate was adjusted by recording the influent water using a beaker.

The experimental setup is illustrated in Figure 1, whereby nine reactors were operated in parallel. The effective volume was set to be 10 liters. Eight of the reactors were filled (approx. 50\%) with biomedia and one left blank as a control.

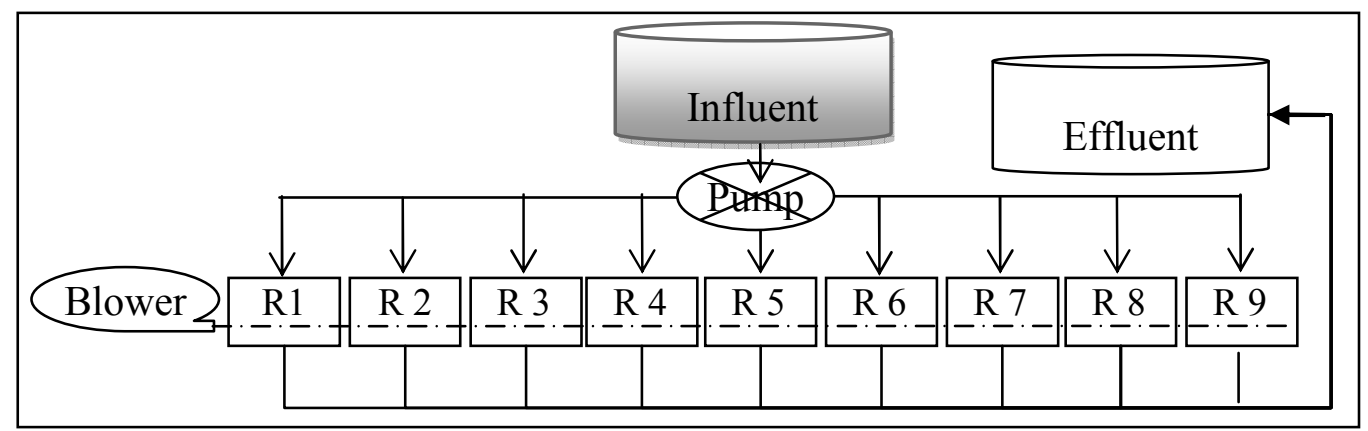

Figure 1: Experimental setup 
Biomedia was installed in the tank following the supplier requirements for the floating and fixed biomedia. The properties and types of selected biomedia used in the experiment are shown in Table 1. The feeding tank was of 1000 liters volume and connected to a feeding pump with delivery pipes to the reactors. Air blower with stone diffusers were also installed.

Table 1: Overall biomedia physical properties

\begin{tabular}{|l|l|l|l|l|l|}
\hline Type & Material & Shape & Surface area & Reactor & Condition \\
\hline 1 & PE & Spherical & $160 \mathrm{~m}^{2} / \mathrm{m}^{3}$ & 7 & Float \\
\hline 2 & HDPE & Netcaged & $140 \mathrm{~m}^{2} / \mathrm{m}^{3}$ & 3 & Fixed \\
\hline 3 & PP & Brush & $49.4 \mathrm{~m}^{2} / \mathrm{m}^{3}$ & 1 & Fixed \\
\hline 4 & BCF & Triple helix string & $>1.0 \mathrm{~m}^{2} / \mathrm{m}^{3}$ & 5 & Hanging \\
\hline 5 & PE/PP & Spherical & $500 \mathrm{~m}^{2} / \mathrm{m}^{3}$ & 4 & Fixed \\
\hline 6 & PVC & Corrugated layer surface & $243 \mathrm{~m}^{2} / \mathrm{m}^{3}$ & 2 & Fixed \\
\hline 7 & PP & Spike ball & $129 \mathrm{~m}^{2} / \mathrm{m}^{3}$ & 9 & Float \\
\hline 8 & Gravel & - & - & 8 & Fixed \\
\hline 9 & Blank & - & - & 6 & - \\
\hline
\end{tabular}

The water samples were collected from influent and effluent points and tested for $\mathrm{pH}$, biochemical oxygen demand (BOD), chemical oxygen demand (COD), Ammonia Nitrogen (AN), total suspended solid (TSS), volatile suspended solid (VSS), total volatile solid (TVS) and dissolved oxygen (DO). The assessments were made based on the collected water samples from each reactor. Parameters were measured according to the Standard Methods for the Examination of Water and Wastewater [13]. Furthermore, optical microscopy was also used for Biofilm assessment on the media fortnightly. For parameter recording, the water sample was taken from the influent tank and reactor tank on daily basis for $\mathrm{DO}$ and $\mathrm{pH}$ (feedwater and reactor tank), and weekly basis for TSS (feedwater and reactor), TVS (carrier), COD (feed and reactor tank), BOD (feedwater and reactor tank). Biweekly monitoring was done to monitor the biofilm by optical microscopic.

\section{Results and discussion}

Two parameters were recorded on daily basis namely DO and $\mathrm{pH}$. Both parameters were recorded for the purpose of monitoring the feeding and reactor tanks to provide livable condition for microorganisms. All reactors and the feeding tank have the same pattern of DO reading. From day one, DO level shows satisfactory result with minimum $5.90 \mathrm{mg} / \mathrm{L}$, as it is important to maintain DO level within $4.0 \mathrm{mg} / \mathrm{L}$ [14]. The $\mathrm{pH}$ values range from 6.3 to 8.4 , and it was observed that $\mathrm{pH}$ tend to decrease after lake water is fed. The effluent from all reactors shows similar trend of $\mathrm{pH}$ elevation with average 7.92. These results were within the limit set by National Water Quality Standard (NWQS) for Malaysian River and Lake Water quality, class II ranges from 6.5 to 9.0.

The average effluent $\mathrm{BOD}_{5}$ value was $36 \mathrm{mg} / \mathrm{L}$, the lowest $\mathrm{BOD}_{5}$ effluent $(24 \mathrm{mg} / \mathrm{L})$ was Reactor 5 with the highest removal rate. The second highest removal rate is Reactor 7, followed by Reactor 4 . The COD for Reactor 8 was the highest removal value with concentration of $73.9 \mathrm{mg} / \mathrm{L}$, followed by Reactor 5 and Reactor 4 . The average value for feeding influent is $144.3 \mathrm{mg} / \mathrm{L}$ (Class V). The TSS data is critical in observing the operational behavior and solids inventory of the system which determines when to waste and/or recycle sludge. The average value for Influent is $195 \mathrm{mg} / \mathrm{L}$ (Class IV for TSS). The lowest average value for reactor is reactor 4 with $37 \mathrm{mg} / \mathrm{L}$ (Class IIA for TSS), followed by reactor 5 with $49.2 \mathrm{mg} / \mathrm{L}$ (Class IIA for TSS) and reactor 7 with $56 \mathrm{mg} / \mathrm{L}$ (Class III for TSS). The average VSS value for feeding tank is $151.3 \mathrm{mg} / \mathrm{L}$ which is classified under medium concentration of wastewater [15]. The lowest average VSS in the reactor is Reactor 4 with 47.2 $\mathrm{mg} / \mathrm{L}$ (weak concentration of domestic wastewater). This is followed by Reactor 5 and Reactor 6 (Blank Reactor); $55.5 \mathrm{mg} / \mathrm{L}$ and $67.3 \mathrm{mg} / \mathrm{L}$ (weak concentration of domestic wastewater). Excessive Ammonia Nitrogen in waterways can cause taste and pungent odor problems [15]. The biofilm process has been satisfactorily used for nitrification process in the water [16,17 and 18]. In this study the $\mathrm{NH}_{3}-\mathrm{N}$ average value in the feeding tank is $2.41 \mathrm{mg} / \mathrm{L}$, and shows that the effluent 
concentration from reactor 2 , reactor 5 , reactor 7 , reactor 8 and reactor 9 were satisfactory. Total Volatile Solid (TVS) is used as an indicator of biofilm formation and the measurement is an approximation of the amount of organic matter present in the solid fraction. Biomedia Type 4 indicates the best performance of biofilm formation, which ended with $7.37 \mathrm{~g} / \mathrm{L} / 5 \mathrm{~cm}$ length of string. The second best performance is Type 7 with $5.43 \mathrm{~g} / \mathrm{L} / \mathrm{unit}$ ball, while third best performance is Type 1 with TVS value of 3.06 gram/L/unit ball.

At the end of the experiment, the final results were compared and the shortlisted biomedia was identified. Table 3 shows the biomedia top three based on performance.

Table 3: Biomedia top three based on performance

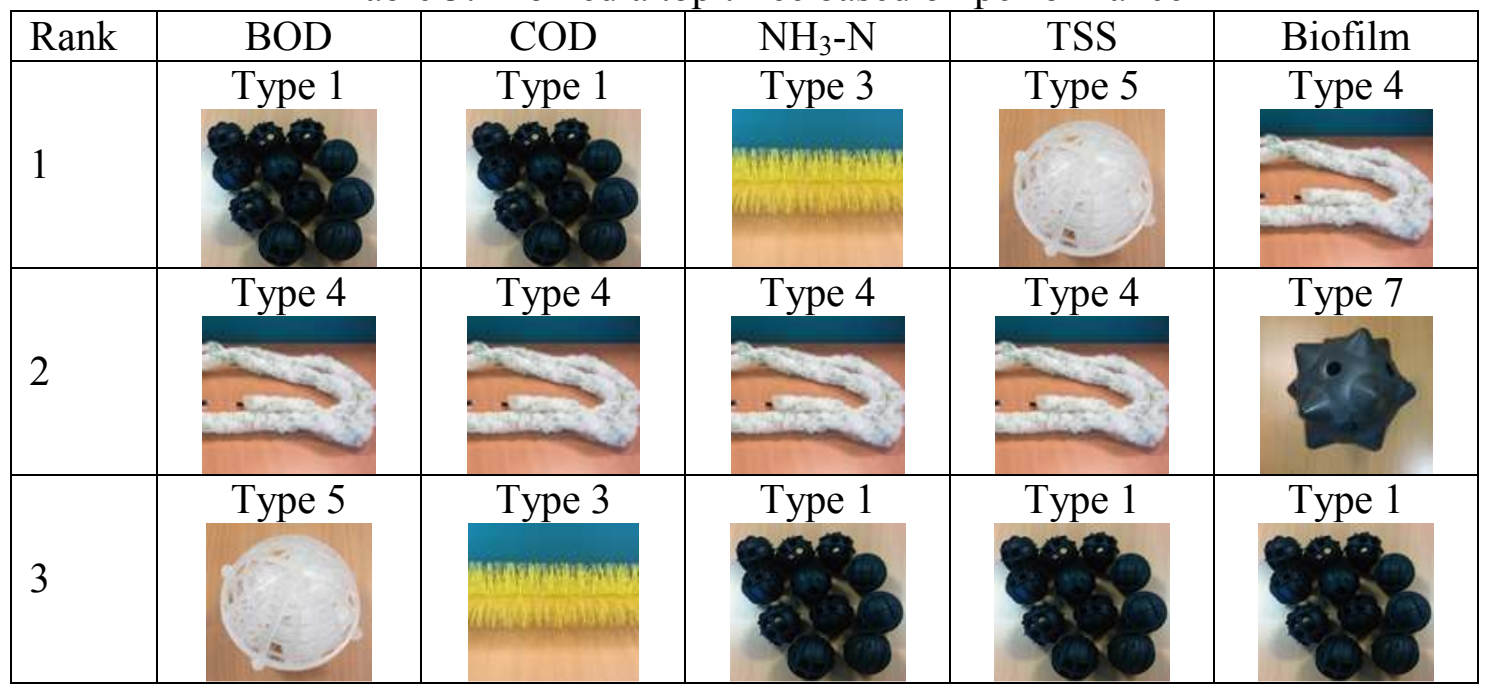

\section{Conclusions}

The biological treatment of river water using several types of biomedia was carried out in this initial stage of evaluation of best attached growth strategy as part of river purification project.

The results indicate that the ball biomedia (Type 1) has achieved the targeted average removal efficiency for BOD and COD with removal efficiency values of $88 \%$ and $65 \%$ respectively. All reactors achieved Class III except for reactors 1 and 2. The overall recommended biomedia are Type 1 (ball) and 4 (string). The study will be continued until biomedia system achieves Class II standard.

\section{Acknowledgement}

This work was supported by the Universiti Tenaga Nasional (UNITEN) and The Department of Irrigation and Drainage (DID).

\section{References}

[1] Performance Management and Delivery Unit (PEMANDU). Economic Transformation Programme. 264 (2012). doi:ISSN : 2232-1411

[2] Mogen Henze, (2008), Biological Wastewater Treatment: Principles, Modeling and Design. IWA Publishing,

[3] Kim, H.-S., Gellner, J. W., Boltz, J. P., Freudenberg, R. G., Gunsch, C. K., \& Schuler, A. J. (2010). Effects of integrated fixed film activated sludge media on activated sludge settling in biological nutrient removal systems. Water Research, 44(5), 1553-61. doi:10.1016/j.watres.2009.11.001

[4] Odegaard, H., Gisvold, G. and Strickland, J. (1998), The Influence of Carrier Size and Shape in the Moving Bed Biofilm Process". Extended abstract for the IAWQ Conference an Biofilm System, New York

[5] Igarashi, T., Watanabe, Y., Asano, T., and Tambo, N. (1999). The Moving Bed Biofilm Reactor, Water Env. Eng. and Reuse of Water, Hokkaido Press, P. 250-305 
[6] Muda, K.,Aris., A., Salim, M,R., Z., Yahya, A., van Loosdrecht, M.C.M., Ahmad, A., Nawahwi, M.Z, (2010) Development Of Granular Sludge For Textile Wastewater Treatment . Water Research, Vol. 44, 4143-4159

[7] George Tchobanoglous, (2002), Wastewater Engineering, Treatment, Disposal and Reuse 3rd Edition. McGraw Hill Inc.

[8] Department of Irrigation and Drainage Malaysia. Briefing on River Cleaning Under the River of Life Project. 35 (2012)

[9] Department of Environment Malaysia. (2013). Malaysia Environmental Quality Report 2012. (Report No. MEQR-2012). Putrajaya. OMR Press Sdn. Bhd.

[10] Hayder, G., Sidek, L. M., Mohiyaden, H. A., \& Basri, H. (2014). Water Quality Index Score of Different Biomedia for River Water Treatment. In 13th International Conference on Urban Drainage, Sarawak, Malaysia.

[11] Department of Irrigation and Drainage - DID, Malaysia. (2009). Water Resources Publication No. 21. (Study on the River Water Quality Trends and Indexes in Peninsular Malaysia).

[12] Azizi, S., Valipour, A., \& Sithebe, T. (2013). Evaluation of different wastewater treatment processes and development of a modified attached growth bioreactor as a decentralized approach for small communities. The Scientific World Journal, 2013.

[13] APHA, 2005. Standard Methods for the Examination of Water and Wastewater. American Public Health Association, Washington DC.

[14] Weiss, J. S., Alvarez, M., Tang, C. C., Horvath, R. W., \& Stahl, J. F. (2005). Evaluation of moving bed biofilm reactor technology for enhancing nitrogen removal in a stabilization pond treatment plant. Proceedings of the Water Env Fed, (14), 2085-2102.

[15] Metcalf and Eddy (2003), Wastewater Engineering: Treatment and Reuse, International Edition, McGraw-Hill, Boston, Massachusetts.

[16] Hem, L. J., Rusten, B., and Odegaard, H. (1994) Nitrification in a Moving Bed Biofilm Reactor, Water Research, 28, 1425.

[17] Odegaard, H., Rusten, B. and Westrum, T. (1994) A New Moving Bed Biofilm Reactor; Applications and Results, Water Science and Technology, 29, 157.

[18] Rusten, B., Kolkinn, O., \& Odegaard, H. (1997). Moving bed biofilm reactors and chemical precipitation for high efficiency treatment of wastewater from small communities. Water science and technology, 35(6), 71-79. 